enter the room for ten days after the operation. One might naturally have expected that after so much violence had been done to the peritoneum some inflammation would have followed. There were twenty-three ligatures cut off short and left in the peritoneal cavity, and the stout ligatures around the pedicle, and eighteen ligatures cut off short and left embedded in the abdominal wall. The escape of so much cystic fluid into the abdominal cavity increased the risk, for, however carefully the cavity might be sponged, some portion would surely remain; but during the whole progress of the case the highest point of temperature reached was $100^{\circ} 2^{\circ}$, and the pulse never exceeded 116. A large amount of carbolic acid was necessarily absorbed during the operation; it undoubtedly caused some renal congestion and partial arrest for some days of the renal secretion; but, on the whole, it did much more good than harm, for I am firmly convinced that had not the strictest Listerism been observed in the treatment of this case, I should have lost my patient.

Rome.

\section{CASE OF STARVATION AND SUSPENDED ANIMATION.}

BX EDWARD BERDOE, M.R.C.S., L.R.C.P.EDIN.

I wAs called on April 29th, 1885, by an order from the relieving officer of my district, to see a man named Samuel B- aged seventy-four, at the almshouses of the Parmiter Charity, Bethnal-green. I found him lying on the floor insensible and dying. His wife sat near him, and on being questioned admitted that he had been lying in the same position for six days without food, drink, or any attention whatever. It was only by information from a neighbour that the parish authorities got to know of it. On raising him to place him on the bed, part of the flesh of his face adhered to the floor and was torn off. The exact form of the patient was marked on the floor by the exudation from the skin. He was in a most filthy state, and though unable to swallow even liquids, lived about fourteen hours after my first visit. By the coroner's order I made a post-mortem examination. The body was fearfully emaciated, and all the parts that had been in contact with the floor were gangrenous. The organs presented the usual appearances of death from starvation, but the medical interest of the case was found in the condition of the heart. This was enormously hypertrophied and dilated; all the vessels were atheromatous, and there was a large aneurysm of the arch of the aorta. The cardiac condition seemed to satisfactorily clear up some of the difficulties of the case. From the evidence at the inquest it is probable that the wife's statement was correct, that he had fallen down "in a fainting fit" six days previous to my visit, and had not moved or spoken since. The heart presumably beat with just sufficient force to keep the respiratory organs going; this was, of course, favoured by the recumbent position. The case is interesting from a medico-legal point of view, as showing how long a person may live in a state of syncope.

Victoria-park-gate, $\mathrm{E}$.

\section{A NEW SPLINT FOR THE TREATMENT OF COMPOUND INJURIES AT OR ABOUT THE ELBOW-JOINT.}

BY ROBERT JONES, M.R.C.S. HOYORARY ASSISTAYT-SLRGEON, STANLEY HOSPITIL, IITERPOOL.

I HAVE found the annered figured splints very useful amongst the out-patients of the Stanley Hospital. One form (Figs. 1 and 2) is composed of two very flexible sheetiron splints covered with felt, and connected by means of a firm iron rod, so twisted as to extend beyond the elbow, leaving ample freedom for easy change of dressings, without interfering with the immobility of the joint. This is of

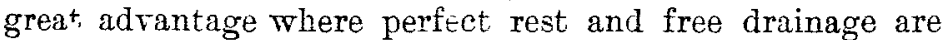
requisite. For comfort's sake the forearm support is extended beyond the wrist-a detail which should on no account be neglected. The connecting bar must be sufficiently strong to admit of no movement at the elbow. Where the wound is unusually large and extends up the arm, I use a modified splint (Figs. 3 and 4), the flexible sheet-iron support being substituted by small wings, which are quite easily bent and can be moulded to the arm without any trouble. The splint is made at any angle which the

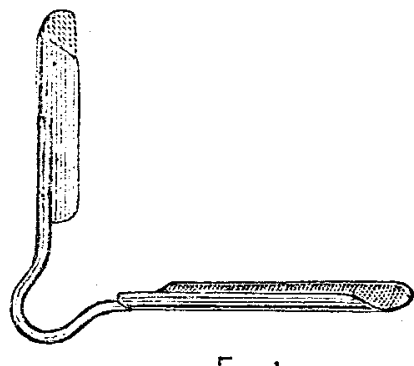

$F_{10} 1$

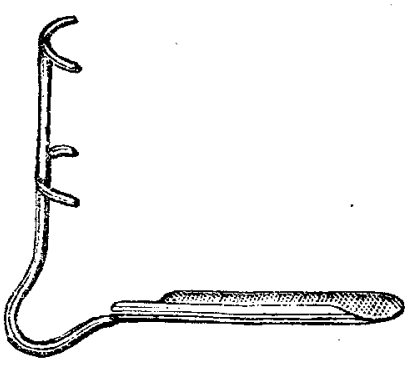

FIG.3
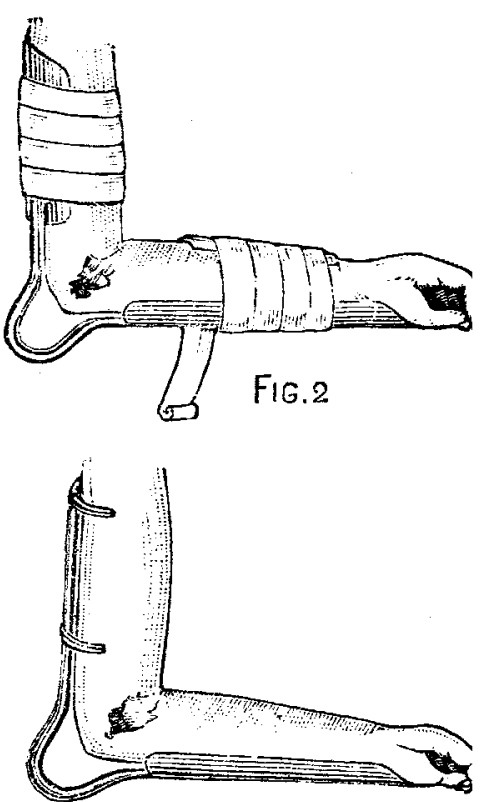

Fig. 4. surgeon, regardful of the possibility of ankylosis, may suggest. This will vary according to the patient's vocation. Generally speaking, a right angle gives the most useful result.

The splints may be procured at a moderate cost from Messrs. Krohne and Sesemann, London; and from Mr. J. Critchley, Upper Pitt-street, Liverpool.

Liverpool.

\section{d a dirtor}

\section{HOSPITAL PRACTICE, BRITISH AND FOREIGN.}

Nulla autem est alia pro certo noscendi via, nisi quamplurimas et morborum et dissectionum historias, tum aliorum tum proprias collectas habere, et inter se comparare.-MorgagnI De Sed. et Caus. Morb., lib. iv. Procmium.

\section{KING'S COLLEGE HOSPITAL.}

A CASE OF EMBOLISII OF THE RIGHT MIDDLE CEREBRAI ARTERY STIULTANEOUSLY WITH EMBOLISM OF THE RIGHT BRACHIAL; GANGRENE OF THE RIGHT THUMB AND LITTLE FINGER; RECOVERY.

(Under the care of Dr. JoHNson.)

IT is rare to have embolism of a cerebral vessel and simultaneous embolism of one of the large systemic arteries. The most common source of such embolism is the detachment of granulations from one of the valves on the left side of the heart. This condition of the valves is usually accompanied by a murmur or other indication of the disease, but it is possible to have disease sufficient to produce embolism of more than one vessel without any murmur. Under such circumstances, until a post-mortem examination has been made, such source cannot be decidedly negatired.

For the following notes we are indebted to Mr. T. Sydney Short, medical registrar.

E. W - - aged thirty-nine years, was brought in by his wife, and carried on an ambnlance stretcher. He could answer questions, but was incoherent and dazed. His wife said that on the night of March 11 tll, serenteen days before his admission, which took place on 1 arch $28+h$, he had a fit when apparently asleep, and she found him out of bed and trying to get into bed again. He was completely dazed, and could only just understand what was said to him. She 